\title{
De \\ verpleegkundestudent in 2025
}

\author{
We verplaatsen ons naar 2025, de coronacrisis ligt alweer enige tijd \\ achter ons. Welke lessen hebben we geleerd over het opleiden van \\ verpleegkundigen? Een kijkje in de toekomst, aan de hand van \\ een fictieve student.*
}

tekst Jeroen Wapenaar illustratie Bernet Ragetli

\section{MAANDAG 24 MAART 2025}

\section{Vlogs en podcasts}

Mila’s stage in het ziekenhuis zit er bijna op, het is nu haar beurt om een vlog te maken voor studenten die na haar komen stagelopen. Sinds de coronacrisis in 2020-2021 delen stagiaires via vlogs en podcasts hun ervaringen met andere studenten en verpleegkundigen. Vanwege de enorme druk op de zorg en alle andere beperkingen was het in 2020 en 2021 veel lastiger om studenten warm welkom te heten. Zorginstellingen waren al langer bezig met nieuwe manieren om studenten te informeren, maar het inzetten van vlogs en podcasts van (oud-)stagiaires nam in de coronajaren een hoge vlucht. Stagiaires zijn beter voorbereid en werkbegeleiders gebruiken de vlogs en podcasts als feedback. Een werkbegeleider leert ook van studenten die zij niet zelf begeleid heeft. ${ }^{1}$

\section{Stagebegeleiding: rol voor oudere ver- pleegkundigen}

In haar vlog vertelt Mila over haar eerste intramusculaire injectie. Typisch zo'n handeling die voor studenten spannend blijft, hoe vaak ze ook oefenen met simulator, pop of fantoom. Mila is een van die studenten die zich ondanks een zelfverzekerde uitstraling toch vaak onzeker voelen. Ze roemt in haar vlog werkbegeleider Anita, die nog voor Mila iets zei vroeg hoe dit voor haar was. Anita gaat over enkele jaren met pensioen en heeft bij haar afdelingsmanager gevraagd om stagiaires te mogen begeleiden, in plaats van werk te doen waar ze geen energie en passie meer voor heeft. Ten tijde van de coronacrisis waren er (alweer) allerlei rapporten verschenen met adviezen over loopbaanperspectief voor verpleegkundigen. Geef ervaren verpleegkundigen meer ruimte om stagiaires te begeleiden,

\section{In het onderwijs is vastgehouden aan de mogelijkheid bepaalde colleges vanuit huis te volgen}




\begin{abstract}
gehad, en wil het liefst zo snel mogelijk naar huis. Haar werkbegeleider benadrukt dat het protocol voor stagebegeleiding niet voor niets een dagevaluatie aanbeveelt: 'Anders ga je met een vol hoofd naar huis en verwerk je spanningen mogelijk niet.' Ze nemen de dienst door aan de hand van de 3-vragen-methode, die werd getoetst tijdens de coronacrisis en behulpzaam bleek bij het omgaan met emotionele belasting. ${ }^{2}$ Anita vraagt Mila (1) welke gebeurtenissen haar zijn bijgebleven, (2) hoe ze zich lichamelijk en mentaal voelt en (3) of ze genoeg steun ontvangt. Mila vertelt dat het verdriet van de dochter van een patiënte haar heeft aangegrepen. De patiënte zakte heel snel weg, hebben ze wel genoeg voor haar gedaan? De dochter zei gezien te hebben hoe hard Mila voor haar moeder heeft gewerkt. 'Dus dat is al een reden om niet aan jezelf te twijfelen', benadrukt Anita. 'En je hebt hoofdpijn? Je weet dat we een

\section{De studenten willen veel ballen tegelijk in de lucht houden, het blijft een uitdaging om ze hierbij te helpen}

WOENSDAG 26 IMAART 2025 Online onderwijs

In het onderwijs is vastgehouden aan het online aanbieden van lessen: studenten kunnen bepaalde colleges vanuit huis volgen. Voor het oefenen van verpleegtechnische vaardigheden gaan studenten nog naar school, net als voor vakken als motiverende gespreksvoering. Dat is trouwens een nog belangrijker vak geworden, want preventie en aandacht voor positieve gezondheid nemen een prominentere plek in de zorg in, en daarvoor doen de studenten bijvoorbeeld veel rollenspellen in de klas. Maar een college over wetgeving kan een student thuis online volgen. Mila kiest daarvoor, en bespreekt later in een breakout room (manier om tijdens videovergaderen sessies te splitsen), de ethische kwesties rondom recente wetswijzigingen.
\end{abstract} ontspanningsstoel met massagefunctie hebben, maak daar gebruik van', adviseert ze. Je moet het ze echt vaak zeggen, weet de werkbegeleider. Of Mila genoeg steun heeft van collega's en omgeving, wil Anita nog weten. Gelukkig wel, antwoordt Mila: ze deelt haar ervaringen met collega's en medestudenten.

\section{Begeleiding via beeldbellen}

Heel fijn, collega's meteen dichtbij voor steun, maar hoe gaat dat in de wijk, vraagt Mila zich thuis af. Medestudent Evi, die stage loopt bij een thuiszorgorganisatie, vertelt dat er een vast moment is waarop ze face-to-face met verpleegkundigen en verzorgenden IG haar dilemma’s kan bespreken. Ook kan ze online zien welke begeleider of andere collega beschikbaar is voor beeldbellen. Toevallig was dat gisteren heel fijn, toen Evi voor het eerst meeging naar een cliënt in de laatste levensfase.

\section{Rol social media}

Met instemming van alle betrokkenen maakt Evi er stories over en tagt bekende journalisten op sociale media. Evi wil haar marketingskills ontwikkelen en daar maakt haar stage-instelling graag gebruik van. Een werkbegeleider zou graag een training social-mediamarketing regelen voor Evi, al moet ook in 2025 elk dubbeltje worden omgedraaid in de zorg. Hij ziet een win-win voor de organisatie: Evi kan meerdere passies kwijt en het imago van de wijkverpleging wordt verder opgepoetst. Er is meer dan de ic, die boodschap overbrengen was de afgelopen jaren een belangrijk doel. Stagiaires in de wijk daarvoor inzetten lijkt een logische zet.

\section{Veel ballen in de lucht}

Voor studenten als Mila geeft online onderwijs meer mogelijkheden het privéleven, school en werk te combineren. Het blijft voor docenten en werkbegeleiders wel een uitdaging deze generatie daarbij te helpen. Ze willen zoveel ballen in de lucht houden ...

Mila denkt tussen de bedrijven door ook aan haar eigen initiatieven voor meer activiteiten in de wijk voor mensen met dementie en hun mantelzorgers. Dan heeft ze voor deze en volgende week nog 3 webinars en e-learnings staan, met verpleegkundigen die ze graag volgt op Instagram en LinkedIn. En ze is net uitgenodigd voor een discussie op de nieuwste praatapp. Die - toevallig of niet - gaat over het verminderen van stress en grenzen stellen als verpleegkundige. 


\section{Digitale technieken}

Meer investeringen in digitale technieken is een ander gevolg van de coronacrisis. Mila heeft veel baat gehad bij het oefenen met virtual reality (VR)-brillen. Daarmee kun je in een VR-omgeving verpleegkundige vaardigheden oefenen. Zoals een neusmaagsonde inbrengen bij een patiënt, die meteen reageert op hoe je te werk gaat. In 2025 is ook het aantal zorginnovatiecentra (ZIC's) in instellingen en op hogescholen flink uitgebreid. Studenten en afgestudeerde verpleegkundigen hebben mede daardoor meer mogelijkheden hun ervaringen met technieken als VR-brillen te delen, en ze indien nodig te verbeteren.

\section{Alternatieve stageplaatsen \\ Overgebleven uit de coronapandemie is dat studenten, zowel op mbo- als hbo-niveau, mee kunnen helpen in vac- cinatiecampagnes, als vervanging voor (een deel van) hun stage. Het tekort aan ervaren werkbegeleiders is nog steeds hoog, mede daarom krijgen vierdejaars studenten meer mogelijkheden stagiairs te begeleiden. \\ Steeds vaker hebben Mila en de sta- gebegeleider van school digitaal overleg. Het voordeel is dat Mila vaker feedback kan krijgen. Tegelijk merken studenten, net als hun voorgangers in 2021, dat vol- waardige stagebegeleiding om meerdere redenen niet altijd lukt in de zorg.}

\section{DONDERDAG 27 MAART 2025}

\section{Niet alles hoeft meteen}

In de coronatijd werd veel meer mensen duidelijk wat een prachtig vak verpleegkunde is, maar ook hoe zwaar het kan zijn. Docenten en leidinggevenden doen veel moeite om studenten te laten zien hoeveel mogelijkheden er zijn voor spe-

\section{Met vlogs en podcasts willen instellingen studenten een welkomstgevoel geven}

cialisatie, maar ook hoe belangrijk het is om veel vlieguren te maken. Het is ook in 2025 nog een grote uitdaging om studenten carrièremogelijkheden te bieden waar ze reikhalzend naar uitkijken, maar ze ook te waarschuwen: niet alles kan en hoeft in een paar jaar.

\section{Loopbaanpaden}

$\mathrm{Nu}$ haar stage er echt bijna op zit, neemt Mila nog eens de loopbaanpaden bij haar werkgever door. Ze kan op de website behalve schema's ook virtuele impressies en interviews met verpleegkundigen van verschillende specialisaties bekijken. Zij leggen uit waar je als student aan moet werken als je zelf die richting op wilt. Zo krijgen studenten een beter beeld van de mogelijkheden om zich te ontwikkelen.

\section{Combibanen}

De ontwikkeling van combibanen is doorgezet: er zijn meer mogelijkheden om het werken op verschillende afdelingen te combineren. Tegelijkertijd in de zorg en in een andere sector kunnen werken was ook een veelgenoemd voorstel in 2021, maar dat is in 2025 nog uitzonderlijk.

\section{Meer inspraak, ook voor studenten Verpleegkundigen werden tijdens de coronagolven uiteindelijk volwaardig on- derdeel van het crisisteam. Managers en bestuurders kregen in de gaten hoe waar- devol de adviezen van verpleegkundigen zijn. Op papier hebben verpleegkundigen dan ook meer zeggenschap gekregen. De}

\section{Steeds vaker hebben Mila en de stagebegeleider digitaal overleg; zo kan Mila vaker feedback krijgen}

diverse verpleegkundige organen zoals de VAR, en de (oud-)verpleegkundigen die inmiddels in besturen participeren, verzamelen ook ideeën van studenten.

\section{Laat je zien}

Mila gaat nog een stap verder: vandaag geeft ze in een populaire talkshow een interview over de eerder genoemde VR-brillen. Om nog even te ontspannen leest ze een oude Nursing uit 2021. Daarin melden vakbonden dat sommige verpleegkundigen tijdens de coronacrisis geen interviews mochten geven (zelfs geen positieve), en dat ze zeker geen toestemming kregen om in uniform aan tafel te verschijnen, 'want dat is eigendom van de instelling'. ${ }^{3}$ Zou dat nog steeds zo zijn, vraagt Mila zich af terwijl ze haar eigen uniform in de spiegel bewondert.

\section{* Deze casus is gebaseerd op informatie uit wetenschappelijk onderzoek, arti- kelen van zorginstellingen, een vooruit- ziende blik, gezond realisme (en hier en daar wat wishful thinking).}

Met dank aan Cindy de Bot, docent Verpleegkunde en senior onderzoeker bij de lectoraten Leven Lang in Beweging en Zorg rond het Levenseinde van Avans Hogeschool, en Esther van Loon, coördinator verpleegkundig onderzoek bij Rijnstate Ziekenhuis.

\footnotetext{
Noten

1 Het Martini Ziekenhuis is zo'n ziekenhuis dat vlogs door studenten introduceerde. www. martiniziekenhuis.nl, nieuwsbericht 15 maart 2021.

2 Meer over dit onderzoek, met een animatie, staat op zonmw.nl, zoek op 3-vragen-methode.

3 Wapenaar J, Pronk in 2021 met je veren (en daarna), 30 december 2020, nursing.nl
} 